Research Article

\title{
Guidance Needs of Adolescents Studying in Jawahar Navodaya Vidyalaya: A Study of Jawahar Navodaya Vidyalaya, Kunihar, District Solan, Himachal Pradesh
}

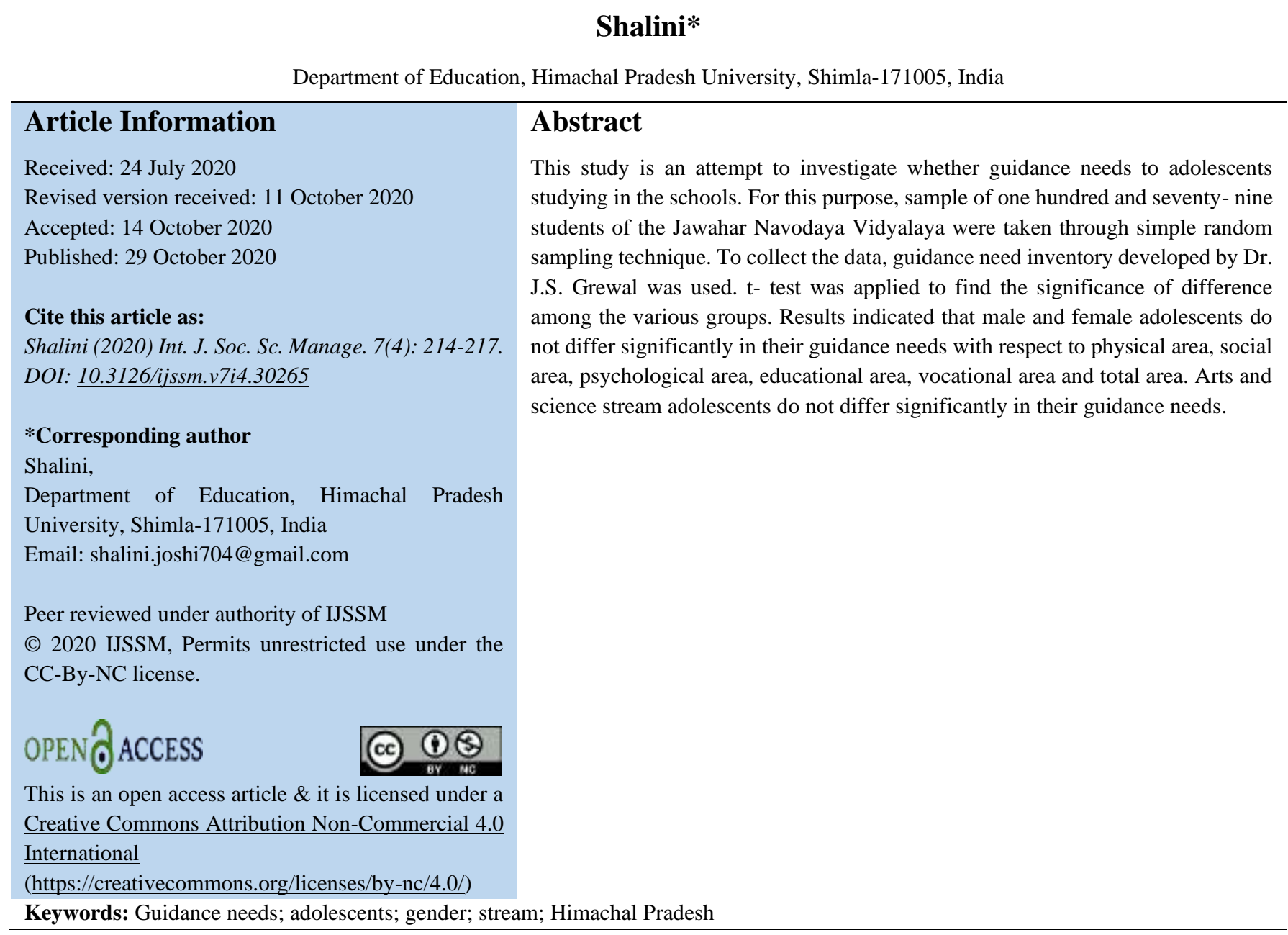

\section{Introduction}

Education, in the present-day context, is perhaps the single most important means for individuals to improve personal endowments, create capacity levels, overcome constraints and in the process, enlarge their available set of opportunities and choices for a sustained improvement in wellbeing. It is not only a means to enhance human capital, productivity and, hence, the compensation to labour, but it is equally important for enabling the process of acquisition, assimilation and communication of information and knowledge, all of which augments a person's quality of life. Education is important not merely as means to other ends, but it is an attribute that is valued in itself by most individuals. More importantly, it is a critical invasive instrument for bringing about social, economic and political inclusion and a durable integration of people, particularly 
those 'excluded' from the mainstream of any society (Aggarwal ,1993).

Guidance is as old as civilization. In the primitive society, elders in the family offered guidance to the young and to persons in distress. Even today, in India, guidance, whether in educational, vocational or personal matters, is sought from family elders. Guidance -unorganized and informal in all places and at all levels has been a vital aspect of the educational process. With the passage of time, revolutionary changes have taken place in the fields of agriculture, industry, business and medicine, etc. (Chauhan, 1982). These changes in all walks of life, coupled with the extraordinary growth in our population have made the social structure very complex. Head of the family or leader of the community with a limited knowledge of the changed conditions is hardly competent in providing guidance and counselling to the youth of today. Hence, there is a need for specialised guidance services. In this lesson, we will try to interact with you regarding the meaning and nature of guidance, its need and scope in India (Aggarwal, 1993).

The need for guidance had existed at all times. Moreover, the need for direction is universal. It is as old as man himself. It is based upon the fact that all human beings need help in one way or other way. "There's hardly any individual who does not need any help." Jones has rightly said, "Everyone needs assistance at some stage in his life. Some will need constantly and throughout their entire life, while others will need it only at rare intervals at times of great crisis. There always have been and will continue to be people with an occasional need for the help of the older or more experienced associates in meeting problem situation." But there is a greater need for guidance services now than ever before due to the rapid advancement in technology, emerging of new world order, social change, globalisation, liberalisation, the need for outstanding leadership, a shift in standards of morality and integrity, people's high aspirations etc. all contribute to the need for guidance programme in the schools.

The scope of guidance is all pervading. Its scope is very vast in the light of modernization and industrialisation and is ever increasing. As the life is getting complex day by day, the problems for which expert help is needed are rapidly increasing. The scope of guidance is extending horizontally too much of the social context, to matters of prestige in occupations, to the broad field of social trends and economic development.

Crow and Crow (1962) have rightly quoted, "As now interpreted, guidance touches every aspect of an individual's personality-physical, mental, emotional and social. It is concerned with all aspects of an individual's attitudes and behaviour patterns. It seeks to help the individual to integrate all of his activities in terms of his basic potentialities and environmental opportunities."
In the present scientific age, increasing complexities of life are becoming responsible for the need of guidance. All of us have some goals in life. Sometimes the goal one sets for oneself may be unrealistic and beyond reach. Perhaps someone trained in this job would be able to analyse our capabilities and help us to set goals that are realistic. There is need for guidance from the point of view of the society as well as of the individual. Among the many needs that human beings seek to fulfil, need for guidance is the most basic. It is in guiding and nurturing human potential especially during the growing years that the foundation of healthy growth and development for the entire life is laid. The country's success in various fields of life depends on the proper guidance of adolescents.

The students need guidance at every step of their life mainly when they are in growing and changing period of life. Jawahar Navodaya Vidalayas are the residential schools, so students studying in these schools are away from their family members. The research in the field of guidance needs of Jawahar Navodaya Vidalayas students is quite relevant as the area in this field need to explore as it remains intact.

\section{Review of Related Literature}

Considering the importance of review of related literature, the studies conducted by fellow analysts have been presented by the investigators as; Shah (1969) concluded that guidance needs of graduate and graduating students differ significantly towards their family status. Grewal (1971) presented the various differences among the students. The differences are majorly based on educational streams, Humanities and Science Students differ significantly. Boys differ significantly from girls in their level of vocational preference. Gupta (1985) found that guidance programmes were more effectively perceived by students of urban schools as compared to those of rural schools. Guidance programmes have proved to be quite effective for the students and parents associated with urban school than with rural school. Neha Singha (2011) showed that there is no significant difference of male and female, educational streams, urban and rural students of government schools among guidance needs in terms of physical, social, psychological, educational and vocational needs. This has been one of the major changes in the society over the decades. Also, Thapar and Kumar (2015) observed that study habits and guidance needs alone do not affect the academic achievements of the students. There are several factors responsible for the same. Analysing the abovementioned review, it is quite obvious that it is necessary to study the guidance needs of adolescents and the amount of work required has not been done in this field, though there have been some changes over the years. Keeping in view the present study has been proposed to be conducted. 


\section{Significance of The Study}

Guidance has been a vital aspect of education. It caters the needs of students to overcome their problems of learning and adjustment so as to ensure optimum achievement and a profitable placement. The country's success in various fields of life depends on the proper guidance of adolescents. Jawahar Navodaya Vidyalayas are running under residential concept so the students studying in these schools need continues guidance at each step of their life. The adolescents of today are the important hope for the future and hence cannot be ignored in their guidance needs. So, the research work is significant to find out the guidance needs of adolescents studying in Jawahar Navodaya Vidyalaya.

\section{Objectives}

(1) To compare the guidance needs of male and female adolescents studying in Jawahar Navodaya Vidyalayas with respect to following areas: (Physical area, Social area, psychological area, educational area, and vocational area).

(2) To compare the guidance needs of science and arts adolescents studying in Jawahar Navodaya Vidyalayas of Himachal Pradesh on various areas under study

\section{Hypotheses}

(1) There will be no significant difference in Physical, Social, Psychological, Educational, Vocational and Total areas of guidance needs of Male and Female adolescents studying in Jawahar Navodaya Vidyalaya.

There will be no significant difference in Physical, Social, Psychological, Educational, Vocational and Total areas of guidance needs of Arts and Science Adolescents studying in Jawahar Navodaya Vidyalaya.

\section{Delimitations}

(1) The study was confined to district Solan of Himachal Pradesh only.

(2) The study was delimited to the jawahar navodaya vidyalaya of solan district only.

\section{Methodology}

In order to collect data, the survey method was used. For the collection of necessary information for this study, investigator used Guidance Needs Inventory developed by Dr. J.S Grewal. The sample of the study consisted of 179 adolescents of Solan District. In order to test the hypotheses, investigator applied ' $\mathrm{t}$ '-test.

\section{Results and Discussions}

The distribution of sample according to the gender has been presented in Table 1 .

The distribution of sample according to the stream has been presented in Table 2 .
Table 1: Description of sample according to Gender

\begin{tabular}{|c|l|c|c|c|}
\hline Sr. No. & Name of J. N. V & Boys & Girls & Total \\
\hline 1 & J.N.V Kunihar (Solan) & 89 & 90 & 179 \\
\hline
\end{tabular}

Table 2: Description of sample according to Streams

\begin{tabular}{|l|l|l|l|l|}
\hline Sr.No. & Name of J. N. V & Arts & Science & Total \\
\hline 1 & $\begin{array}{l}\text { J.N.V Kunihar } \\
\text { (Solan) }\end{array}$ & 85 & 94 & 179 \\
\hline
\end{tabular}

Analysis of DATA

The analysis of data is presented under following heads:

\section{(A) Gender wise Distribution of Scores on Guidance Needs}

It is observed from Table 3 that the calculated value of ' $t$ ' for ascertaining the significance of difference in mean scores on guidance needs of male and female adolescents came out to be $.499, .989, .943, .569,1.46, .177$ in Physical area, Social area, Psychological area, Educational area, Vocational area and Total areas respectively. It shows that Male and Female adolescents studying in Jawahar Navodaya Vidyalayas do not show a significant difference in their guidance needs even at 0.05 level of confidence in all the areas under study.Therefore the Null hypothesis no. 1 which states that "There will be no significant difference in Physical, Social, Psychological, Educational, Vocational and Total areas of guidance needs of Male and Female adolescents studying in Jawahar Navodaya Vidyalayas " is accepted.

\section{(B) Guidance Needs of Adolescents in Relation to Their Stream}

From the Table 4 it may be seen that the calculated value of ' $t$ ' for ascertaining the significance of difference in mean scores on guidance needs of adolescents came out to be $.852, .013, .665,1.02,1.15,1.06$ in Physical area, Social area, Psychological area, Educational area, Vocational area and Total areas respectively. It shows that Arts and Science adolescents in Jawahar Navodaya Vidyalayas do not show a significant difference in their guidance needs even at 0.05 level of confidence in all the areas under study. Therefore the Null hypothesis no.2 Which states that "There will be no significant difference in Physical, Social, Psychological, Educational, Vocational and Total areas of guidance needs of Arts and Science adolescents studying in Jawahar Navodaya Vidyalayas " is accepted.

The major findings of the study are as under:

1) Male and Female adolescents studying in Jawahar Navodaya Vidyalayas do not differ significantly in their guidance needs with respect to Physical area, Social area, Psychological area, Educational area, Vocational area and Total areas under study.

2) Arts and Science adolescents studying in Jawahar Navodaya Vidyalayas do not differ significantly in their guidance needs with respect to Physical area, Social area, Psychological area, Educational area, Vocational area and Total areas under study. 
Table 3: Mean, S.D and ' $t$ ' values on guidance needs of male \& female adolescents

\begin{tabular}{|c|c|c|c|c|c|c|c|}
\hline Sr. No. & Areas & Gender & Number $(\mathbf{N})$ & $\operatorname{Mean}(\mathbf{M})$ & Standard Deviation $(\sigma)$ & 't'-value & Result \\
\hline \multirow[t]{2}{*}{1} & \multirow[t]{2}{*}{ Physical } & Male & 90 & 11.11 & 5.78 & \multirow[t]{2}{*}{499} & \multirow[t]{2}{*}{ N.S } \\
\hline & & Female & 89 & 11.60 & 7.14 & & \\
\hline \multirow[t]{2}{*}{2} & \multirow[t]{2}{*}{ Social } & Male & 90 & 20.44 & 10.35 & \multirow[t]{2}{*}{.989} & \multirow[t]{2}{*}{ N.S } \\
\hline & & Female & 89 & 33.35 & 123.31 & & \\
\hline \multirow[t]{2}{*}{3} & \multirow[t]{2}{*}{ Psychological } & Male & 90 & 19.19 & 8.46 & \multirow[t]{2}{*}{.943} & \multirow[t]{2}{*}{ N.S } \\
\hline & & Female & 89 & 20.49 & 10.00 & & \\
\hline \multirow[t]{2}{*}{4} & \multirow[t]{2}{*}{ Educational } & Male & 90 & 20.81 & 12.80 & \multirow[t]{2}{*}{.569} & \multirow[t]{2}{*}{ N.S } \\
\hline & & Female & 89 & 19.70 & 13.40 & & \\
\hline \multirow[t]{2}{*}{5} & \multirow[t]{2}{*}{ Vocational } & Male & 90 & 8.69 & 5.85 & \multirow[t]{2}{*}{1.46} & \multirow[t]{2}{*}{ N.S } \\
\hline & & Female & 89 & 7.46 & 5.38 & & \\
\hline \multirow[t]{2}{*}{6} & \multirow[t]{2}{*}{ Total } & Male & 90 & 80.07 & 35.03 & \multirow[t]{2}{*}{.177} & \multirow[t]{2}{*}{ N.S } \\
\hline & & Female & 89 & 79.11 & 37.23 & & \\
\hline
\end{tabular}

df. $=(179-2)=177$

' $\mathrm{t}$ ' value at 0.05 level with $\mathrm{df} .177=1.98$

' $\mathrm{t}$ ' value at 0.01 level with df. $177=2.61$

Table 4: Mean, S.D and ' $t$ ' values on guidance needs of Arts \& Science adolescents.

\begin{tabular}{|c|c|c|c|c|c|c|c|}
\hline $\begin{array}{l}\text { Sr. } \\
\text { No. }\end{array}$ & Areas & Stream & $\begin{array}{c}\text { Number } \\
\text { (N) }\end{array}$ & $\begin{array}{c}\text { Mean } \\
(\mathrm{M})\end{array}$ & $\begin{array}{c}\text { Standard } \\
\text { Deviation } \\
(\sigma)\end{array}$ & 't'- value & Result \\
\hline \multirow[t]{2}{*}{ I } & \multirow[t]{2}{*}{ Physical } & Arts & 85 & 10.92 & 6.12 & \multirow[t]{2}{*}{.852} & \multirow[t]{2}{*}{ N.S } \\
\hline & & Science & 94 & 11.74 & 6.80 & & \\
\hline \multirow[t]{2}{*}{ Ii } & \multirow[t]{2}{*}{ Social } & Arts & 85 & 20.33 & 10.88 & \multirow[t]{2}{*}{.013} & \multirow[t]{2}{*}{ N.S } \\
\hline & & Science & 94 & 20.31 & 10.63 & & \\
\hline \multirow[t]{2}{*}{ Iii } & \multirow[t]{2}{*}{ Psychological } & Arts & 85 & 19.35 & 9.03 & \multirow[t]{2}{*}{.665} & \multirow[t]{2}{*}{ N.S } \\
\hline & & Science & 94 & 20.28 & 9.48 & & \\
\hline \multirow[t]{2}{*}{ Iv } & \multirow[t]{2}{*}{ Educational } & Arts & 85 & 19.20 & 11.64 & \multirow[t]{2}{*}{1.02} & \multirow[t]{2}{*}{ N.S } \\
\hline & & Science & 94 & 21.21 & 14.25 & & \\
\hline \multirow[t]{2}{*}{$\mathbf{V}$} & \multirow[t]{2}{*}{ Vocational } & Arts & 85 & 7.56 & 4.58 & \multirow[t]{2}{*}{1.15} & \multirow[t]{2}{*}{ N.S } \\
\hline & & Science & 94 & 8.54 & 6.44 & & \\
\hline \multirow[t]{2}{*}{$\mathbf{V i}$} & \multirow[t]{2}{*}{ Total } & Arts & 85 & 76.58 & 34.65 & \multirow[t]{2}{*}{1.06} & \multirow[t]{2}{*}{ N.S } \\
\hline & & Science & 94 & 82.32 & 37.24 & & \\
\hline
\end{tabular}

$\mathrm{df}=(179-2)=177$

' $t$ ' value at 0.05 level with df. $177=1.98$

' $t$ ' value at 0.01 level with df. $177=2.61$

\section{Educational Implications}

From the findings of the study, it is clear that adolescents have the same kind of guidance needs.

1) The collective counseling's sessions may be taken to guide the students for various future educational needs apart from their gender and stream.

2) To prepare such an expert group workshop should be organized for the students at national and state level.

\section{References}

Aggarwal JC (1993) Educational vocational guidance and counseling. Doaba House, Nai Sarak Delhi.

Chauhan SS (1982) Principles and techniques of Guidance. Vikas Publishing House pvt. Ltd

Crites, John O (1969) Vocational psychology: The Study of vocational Behaviour and Development. New York: MC Grow Hill book.
Crow LD and Crow (1962) An introduction to guidance principles and practices. New Delhi: Eurasia Publishing House.

Grewal JS (1971) Guidance needs inventory.

Gupta SR (1985) A study of objectives, programmes, infrastructural facilities and perceived effectiveness of guidance services in Delhi schools. Ph. D. Edu., Merrut University.pp.532

Shah (1969) Guidance needs of graduate and graduating students. Third survey of educational research.pp.250.

Singha N (2011) Guidance needs of senior secondary students in relation to Gender, Stream and Locality. Pp 38.

Thapar V and Kumar A (2015) Academic achievement of truents in relation to study habits and guidance needs. International journal of advanced research 3(6): 13441349. 